\title{
ANALYZING THE DEVELOPMENT OF PHONOLOGYCAL ASPCETS IN SPEAKING CLASS TO STUDENTS OF ENGLISH AS A FOREIGN LANGUAGE (EFL) IN JENDERAL SOEDIRMAN UNIVERSITY
}

\author{
Syaifur Rochman \\ Jenderal Soedirman University
}

\begin{abstract}
The differences in phonological systems between Indonesian and English systems are the central problems that university students often encountered in speaking practice. Students usually transfer the system of their own mother tongue to the target language. This article is intended to explore the problems of EFL students in Jenderal Soediman University in speaking the target language correctly. The discussion focused on the typical mistakes that the university students made in phonological aspects. Analysis was given to problems in the aspect which occurred during their speaking class. It was hoped that this could become an idea of the EFL teacher to devise the materials for teaching students in tertiary level.
\end{abstract}

Keywords: phonology, university students in Indonesia, EFL

\section{Introduction}

Many students of the university come to the English Language and Literature Department with prior formal English language learning from their formal institution (i.e., senior high schools), or informal institution (i.e., private English courses). Some of them progress fairly well in acquiring an acceptable level of English pronunciation. Their speech is not accent free, but their pronunciation does not interfere markedly with their communication or otber's attitudes towards them. There are other learners, however, who are unable to communicate efficiently due to their accent and poor pronunciation in English when they start learning EFL. Indonesian students have particularly problems due to the great difference between their native language and English (Bire, 1993).

Training in listening and pronunciation skills has been in the past relatively superficially treated area of Teaching English to Speakers of Other Languages (TESOL), with little research, and until recently, little commercially available 
classroom material (Brewster et.al., 2003). This is particularly so with materials using authentic English accents and dealing with the native dialect of English, like American, British, and Australian (Harmer, 2001).

There is also an assumption amongst many teachers that pronunciation will develop with all areas of communicative competence (Brewster et.al., 2003). There are some experts who do not consider that any special attention should be paid to pronunciation teaching. They believe that learners should be trained in techniques in everyday conversation and social interaction to overcome communication breakdown (Cohen, 1990).

Some teachers even consider that it is self-defeating to correct leamer's problems or make them aware of such difficulties. It is the fact that little attention is paid by teachers to pronunciation needs of students within the limits of their busy teaching time (Doff, 1999). Word stress placement does not receive a certain amount of attention, and this is one of the most significant factors in communication breakdown for Indonesian university students of English.

\section{Approaches in Developing Listening Skill and Pronunciation Practice}

There is a diversity of opinion on the best approach to the development of clear English pronunciation (Hedge, 2002). The materials used for the teachingleaning process should be in a more global approach than pure pronunciation exercise. Pronunciation teaching needs to be integrated into the whole process of listening to and speaking English (Cox, 1999).

Withdrawal of students for special pronunciation classes and allocation of - special times in class for pronunciation training is preferred in some teaching contexts. For instance, students in Diploma III English Department of JenderaI Soedirman University study Pronunciation in a special subject. However, students often find such isolated teaching hard to relate to general language learning. Therefore, the materials used for teaching pronunciation should integrate listening and pronunciation skills, as aural discrimination needs to precede oral production.

Demand for, and expertise in the teaching of the spoken language has developed and the advent of the audio-lingual method. There is, however, an imbalance between listening and speaking, in favor of speaking skills. The assumption is that language is learned by active production and practice (Cook, 1991). Producing language has been seen as an 'active' process, whereas listening is considered as a 'passive' process (Hadley, 2001). 
A particular for language learners in listening comprehension is the little control over the intake of language, since this is largely controlled by the speaker (Scrivener, 1997). With reading, the so-called 'passive' process, the language learners can control the intake. Knowledge has increased recently about the reading process, and the syntactic, and semantic cueing systems by which we predict and understand what we read and the meaning thereof.

Knowledge is increasing about the listening process, the phonological, semantic, and syntactic cueing systems by which we derive meaning from speech (Hadley, 2001). There is a great need for the development of expertise in this area as students may understand and produce English language in an idealized, controlled form in the classroom, but are nit equipped to comprehend authentic spoken English and communicative effectively in the community (Hedge, 2001).

\section{Model for Language Learning}

Research in the first and second language acquisition has produced different models for learning a language. Littlewood (cit. Cook, 1991) outlines a model of creative construction. According to him, the cognitive strategies that learner bring in order to develop internal representations of the language. This creative construction model particularly seeks to explain how learners 'acquire' an underlying knowledge of the language, which is distinct from performance skills. That is 'productive' skill are the external expression of the system internalized at whatever stage of development the learner has reached.

Presumably, the utterances cannot precede the system that generates them. This is not only the true with language forms and structures, but on phonological dimensions of stress, rhythm, and intonation. Learners cannot produce segmental sounds or stress patterns, rhythm, and intonation before they can aurally discriminate them (Doff, 1999).

This creative construction model contrasts greatly with the learning model implicit in most of the current approaches to actually teaching a foreign language (Cook, 1991). The graph below explains the differences of the models.

Graph 1. Creative Constructive Model

\begin{tabular}{|c|c|c|c|}
\hline $\begin{array}{c}\text { input from } \\
\text { exposure }\end{array}$ & $\begin{array}{l}\text { internal } \\
\text { processing }\end{array}$ & $\begin{array}{l}\text { system constructed } \\
\text { by learners }\end{array}$ & $\begin{array}{c}\text { spontaneous } \\
\text { utterances }\end{array}$ \\
\hline
\end{tabular}


Graph 2. Model Underlying Most Teaching

input from

instruction
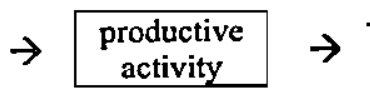

system assimilated

by learners spontaneous

utterances

Most teaching practice is based on the assumption that through producing predetermined examples of language, the productive activity rather than the internal processing will lead them to internalize the underlying system (Harmer, 2001). In the initial stages of children acquiring their native language, aural discrimination and comprehension has the highest priority. Children demonstrate comprehension on many utterances long before they demonstrate any ability to produce intelligible speech (Brewster, 2003). Empirical evidence to substantiate this commonsense notion has been provided by many excellent studies of child language acquisition (Cook, 1991).

Paralinguistic features of language act as signposts to guide the listener through the structure of an utterance (Cox, 1999). When a speaker is making a remark he/she considers to be a central pointing the conversation; the importance will be conveyed by marking and with the paralinguistic features of slow tempo, extended pitch range, precise articulation, extended timing, and stress.

Stress, intonation, and rhythm of the language are important in conveying meaning. Hadley (2001) cites the evidence that in terms of the first language acquisition, infants actually receive stress and rhythm before they learn to perceive phonetic segments. Infants babble with stress and intonation-like rises, and falls from 6-8 months, preceding the production of segments by 6 months.

Similarly, learners of English as a foreign language need to begin with the supra segmental before attempting to master segmental sounds (Hedge, 2002). Stress and rhythm in English take years to acquire for the native speaker. Therefore for the speaker of other languages, it is an area that will develop over time. English language learners need to be exposed to authentic native speech to perceive the rhythm of the language, and the teaching methodology needs to focus on these supra segmental aspects of the language (Harmer, 2001).

\section{Methodology}

This study used a descriptive analysis method to analyze the development of speaking and pronunciation practice. The respondents were students of Diploma 
III English Language Program of English Language in Jenderal Soedirman University. They took a subject called 'Speaking 4 ' in which they were categorized in an advanced level. Students were divided into four parallel classes consisting of 15 students for class A; 12 students for class B; 19 students for class $C$, and 13 students for class $D$.

The researcher acted as the teacher of the subject called 'Speaking 4 '. During the class, the researcher observed, noted down and recorded the activity. After that, the researcher analyzed some incorrect pronunciations of the students. The researcher grouped the common errors that the students made as a basic consideration for deciding what materials should be focused on helping the students to improve their listening skills as well as their pronunciation in the next semester.

While observing for 7 weeks or half of the semester, the researcher also interviewed informally to some of the students regarding their mistakes. The researcher needed to clarify the causes of -the problems that the students encountered. By doing this, an appropriate treatment could be applied to help students improve their listening skills and pronunciation practice, especially in the form of materials that the students used.

\section{Result and Discussion}

The following notes concerned problems that were encountered by students with the pronunciation and the structures of English. The problems applied equally to most the students taking the subject of Speaking 4 . The results were categorized into pronunciation problems and other difficulties.

\section{a. Pronunciation}

There were some vowels that were not representing much difficulty in any position. For instance, students could pronounce [e] as in the word "egg", "bed". However, many students produced too broadly of the vowel, so this tended to be confused with [æ]

Students found problems in pronouncing vowels in one position only. Many students could not pronounce correctly the [?], like in the words of "doctor", and "pocket". The vowel is common in Indonesian in all position except as the final sound of words. Therefore, many students found difficulty in pronouncing words, such as "father", "sailor", and "measure'. 
The chief difficulty likely to be found with [?] was not in its pronunciation, but in its use as a substitute for most vowels, in weakly stressed syllables. The sound [?] in Indonesian was spelt " $e$ ". Students were not accustomed to pronouncing other vowel letters as [?]. Therefore, students had to practice in this intensively.

Due to the fact that all vowels in Indonesian were relatively short, students found problems in distinguishing the vowels which were largely distinguished by vowel length. The difficulty was increased by the fact that the Indonesian language equivalent of each vowel was generally between the members of the pair in phonetic quality. For instance, the Indonesian " $I$ " is tenser than English [i], but not as long as English [i:]. These vowels became problems for students to pronounce.correctly, such as [i:] in the words "even", "leafy" and [i] in the words "if" and "sit". Another vowel was [a:].sưch as in "art", "laugh", "car"; and $[\square]$ in "uيtter" and "cutt".

It was found that students had difficulty in pronouncing some vowels-in English in all positions because these vowels did not have any equivalent vowels in Indonesian. For example, vowels [æ] as in "am" and 'man", and [?:] as in "early", "bird", and "her". For [?:], most students often used the familiar sound [?].

Diphthongs were found in Indonesian, such as [i] as in "oil", "boiling" and "toy"; [ai] as in "I", "mine", and "my"; and [au] as in "owl", "loud, and "now". Actually these diphthongs occurred in Indonesian. However, there were a tendency for students to pronounce [ai] to become [ei] or rather [e(:)], and for $[\mathrm{au}]$ to become [o(:)]. Seemingly, students were confused between [ai] and [ei], and between [au] and [ou]. Examples of diphthongs [ai] and [au] in Indonesian were "berahi" and "menjahit" [ai], and "bahu" and "perahu" [au].

It could be also noted that the above three diphthongs were all a little bit difficult for students when occurred before final consonants, like in "oil", "mine", "town". Where final consonants did follow such vowel combinations in Indonesian, the effect was less diphthongal than elsewhere.

Below were diphthongs that did not occur in Indonesian. As. a result, students found problems when pronouncing them. Those were [iá] as in "ear",

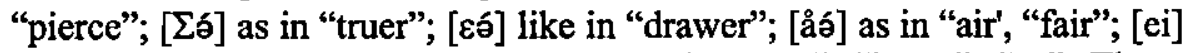
like in "aim", "main", day"; and [ou] as in "own", "home", "so". Those diphthongs had similar vowel combinations in Indonesian such as [ia] as in "rahasia", [ua] as in "dua", [oa] as in "perseroan", and [ea] as in "bea". 
Most students found that the diphthongs [ei] and [ou] were much more difficult. On one hand, the diphthongs were pronounced by most students to become pure vowel, like $[\mathrm{e}(:)]$ and $[\mathrm{o}(:)]$, or [ (:)]. On the other hand, it was found that students were confused with [ai] and [au] as explained earlier.

There were rare triphthongs found in Indonesian that caused problems for students when pronouncing them. For examples, the triphthongs [au?] as in "hour", "tower"; [ai?] as in "iron", fire; [oi?] as in "choir", "employer"; [ou?] as in "blower", "sower"; and [ei?] as in "player", "layer". However, some comparison could be made between English triphthongs and Indonesian ones, like "persemaian", "keramaian", perdamaian", "kepulauan", and "kemauan".

Most students pronounced voiceless stops i.e., [p], $[\mathrm{t}],[\mathrm{k}]$, were unaspirated at the beginning of the words; while, unlike in Indonesian, students had to aspirate them in English. Hence the [p] pronounced by the students was like the English [p] in "sport", no like the English [p] in "port". In Indonesian, the [p] was distinguished from an English consonant [b] only by the absence of voicing in their [p]. It was likely that the English speakers tended to hear Indonesian [p] as a [b], since the absence or presence of voicing was not the only basis for discrimination between [p] and [b] in English.

English contrasts the voiceless and aspiration of an initial [p] with the voicing and lack of aspiration on an initial [b]. The main criterion followed by the English-speakers in identifying whether a syllable-initial stop is voiceless or voiced is the presence or absence of aspiration. Students on the other hand used as their criterion the presence or absence of voice. Therefore, students could not recognize aspirated initial $\left[\mathrm{p}^{\mathrm{h}}\right],\left[\mathrm{t}^{\mathrm{h}}\right]$ and $\left[\mathrm{k}^{\mathrm{h}}\right]$.

There was no voice stop occurred finally in Indonesian. This seemed to be a problem for students to pronounce the words correctly. In Indonesian, [p], [k], $[\mathrm{k}]$ are found at the end o words, but not [b], [d], or [g]. In other words, written "p" or " $b$ " at the end of a word both pronounced as [p] (unreleased). Students pronounced written final " $t$ " or " $d$ " as [ $t$ ] (unreleased). The written final consonants of " $k$ " or "g" were both pronounced as [k] (unreleased).

Most students failed to notice the importance of the ending consonants $[-z]$, [-s], and [-d], [-t] for noun and verb endings in English. Students did not pronounce them after consonants. Thus, students did not distinguish between "love" and "loves" and "loved" ([-s], [-d]) or between "pack", "packs", and "packed" ([-s], [-t]). 


\section{b. Stress, Rhythm, and Other Factors}

An important feature of English, which has no parallel in Indonesian is the linking of words in a sentence so that they flow smoothly and unbrokenly. Linkers such as $[r]$ and $[w]$ are thus inserted in English between a word ending in a vowel sound and a word beginning with a vowel, e.g. contrast [ðعá nju:] (they're new) with [ðع (a) r-ould] (they're old). Students, on the other hand, hand a tendency to clip off each word separately and insert "glottal stops" (a catch of the breath) between them.

Stress is not so clearly marked in Indonesian as in English. Many students stressed the word invariably on the second last syllable since there was a fairly consistent tendency for stress to fall on this syllable of words in Indonesian. - This tendency linked with other difficulties such as final consonant cluster difficulty that led to unintelligible pronunciation such as "even" for "event". Consequently, this would also affect comprehension. Students heard "even" and think they have heard "event" because they always pronounced "event" as "even".

The characteristic sentence rhythm of English was difficult for students because they were lack of linkers and stress. As a result, students' pronunciation of English sentences created their inability to comprehend normal rhythmic English in conversation. All structures should be taught and drilled in natural rhythm.

On the surface, there does not appear to be a marked difference between some of the intonation patterns of English and those of Indonesian. Many students had trouble with the intonation of question. They tended to use an upward intonation in questions beginning with question words, which required a downward intonation in English.

\section{Conclusion}

Students of Diploma 3 English in Jenderal Soediman University need to raise the awareness in phonological aspects when practice speaking. Most of them had little concern with the sounds of English structured. Actually, it is important to recognize that the individual who wishes to leam a new language must learn a new set of phonological rules in the target language.

To pronounce some difficult vowels and consonants in English, Indonesian students could practice the sounds using the minimal pairs. This could prove helpful in contrasting the sounds with those often substituted for them. However, 
many Indonesian students may be able to pronounce the sounds of English quite well and still at times be unintelligible if they fail to achieve mastery of the stress, rhythm, and intonation properly.

\section{References}

Bire, Joshua, (1993). A Research Plan for the Future Evaluation of the English as a Second Language Program in Indonesia. Unpublished M.Ed. Theses. School of Education, La Trobe University: Australia.

Brewster, Jean; Ellis, Gail; dan Girard, Denis (2003). The Primary English Teacher's Guide. Pearson Education: USA.

Cook, V. (1991). Second Language Learning and Language Teaching. Edward Arnold: USA.

Cohen, David (1990). Language Learning Insights for Leamers, Teachers, and Researchers. Heinle and Heinle: USA.

Cox, Carole (1999). Teaching Language Arts. Allyn and Bacon:USA.

Doff, Adrian (1999), Teaching English. Cambridge: Cambridge University Press.

Hadley, Alice Omaggio (2001). Teaching Language in Context. USA: Heinle and Heinle.

Harmer, Jeremy (2001). How to Teach English. Longman: Malaysia.

Hedge, Tricia (2002). Teaching and Learning in the Language Classroom. Oxford University Press: UK.

Scrivener, Jim (1997). Learning Teaching: a Guide for English Language Teachers. Heinemann: UK. 